\title{
BIOINFORMATION
}

Discovery at the interface of physical and biological science.

\section{Antioxidant effects of Emblica officinalis and Zingiber officinalis on arsenic and lead induced toxicity on Albino rats}

\author{
Mohd Fazal1,2, Vishnu Priya Veeraraghavan ${ }^{*}{ }^{*}$, Bushra Tahreen $^{3}$, Selvaraj Jayaraman ${ }^{1}$ \& R. Gayathri1 \\ 1,3,5,6Department of Biochemistry, Saveetha Dental College, Saveetha Institute of Technical and Medical Sciences, Saveetha University, \\ Chennai, India; ${ }^{2}$ Department of Anatomy Government Medical College Siddipet, Telangana, India; ${ }^{3}$ Department of Dentistry, International \\ Dental Care, Banjara Hills, Hyderabad, Telangana, India; *Corresponding author; Dr.V. Vishnu Priya - E-mail: drvishnupriyav@gmail.com
}

\section{Authors Contact:}

Mohd Fazal: fmohd1513@gmail.com; Dr. Bushra Tahreen: bushratahreen92@gmail.com; Dr. Selvaraj Jayaraman: jselvaendo@gmail.com; Dr. R. Gayathri: gayathri.jaisai@gmail.com; Dr Vishnupriya: vishnupriya@saveetha.com; J. Selvaraj: Selvarajj.sdc@saveetha.com

Received January 19, 2021; Revised February 20, 2021; Accepted February 24, 2021, Published February 28, 2021

Declaration on Publication Ethics:

DOI: $10.6026 / 97320630017295$

The author's state that they adhere with COPE guidelines on publishing ethics as described elsewhere at https://publicationethics.org/. The authors also undertake that they are not associated with any other third party (governmental or non-governmental agencies) linking with any form of unethical issues connecting to this publication. The authors also declare that they are not withholding any information that is misleading to the publisher in regard to this article.

Author responsibility:

The authors are responsible for the content of this article. The editorial and the publisher have taken reasonable steps to check the content of the article in accordance to publishing ethics with adequate peer reviews deposited at PUBLONS.

Declaration on official E-mail:

The corresponding author declares that official e-mail from their institution is not available for all authors

\section{Abstract:}

It is of interest to document the effect of Emblica officinalis (E. officinalis) and Zingiber officinalae (Z. officinalae) leaf extract on reactive oxygen species, antioxidant potential changes in arsenic and lead-induced toxicity in male rats. We used 8 groups of adult male Wistar rats with 1 control group for this study. The animals were divided into Group I: Control and Group II: Lead and sodium arsenite induced rats (animals were induced for metal toxicity by the combined administration of arsenic $(13.8 \mathrm{mg} / \mathrm{kg}$ body weight) and lead (116.4 mg/ $\mathrm{kg}$ body weight). These doses were administered by gastric intubation during 14 consecutive days using known standard procedures. Arsenic and lead induced rats treated with ethanolic extract of Emblica officinalis (60 mg/kg body weight/day, orally for 45 days) are group III rats. Group IV animals are arsenic and lead induced rats treated orally with ethanolic extracts of E. officinalis (120 mg/kg body weight/day for 45 days). Group V animals are arsenic and lead induced rats treated orally with ethanolic extracts of Z. officinalae (60 mg/kg body weight/day for 45 days). Group VI animals are arsenic and lead induced rats orally treated with ethanolic extracts of Zingiber officinalis (120 

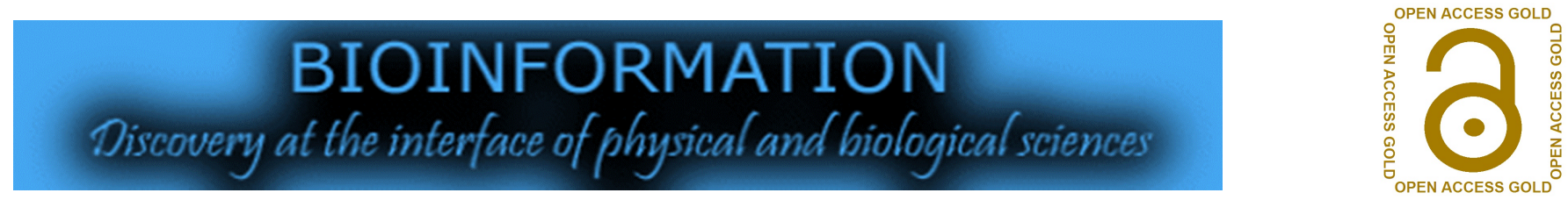

$\mathrm{mg} / \mathrm{kg}$ body weight/day for 45 days). Group VII animals are arsenic and lead induced rats treated orally with ethanolic extracts of E. officinalis and Z. officinalae $(60+60 \mathrm{mg} / \mathrm{kg}$ body weight/day for 45 days). Group VIII animals are arsenic and lead induced rats treated orally with ethanolic extracts of E. officinalis and Z. officinalae $(120+120 \mathrm{mg} / \mathrm{kg}$ body weight/day, orally for $45 \mathrm{days})$. Normal Control animals were treated orally with ethanolic extracts of E. officinalis (120mg/ kg body weight) + Z. officinalae (120mg/ kg body weight) for 45 days. The control and experimental animals were then subjected to analysis for oxidative stress markers such as $\mathrm{H} 2 \mathrm{O} 2$, *OH, and lipid peroxidation (LPO), antioxidant enzymes in addition to liver and kidney function markers. Results: Arsenic and lead induced rats showed a significant increase in the levels of reactive oxygen species $\left(\mathrm{H} 2 \mathrm{O} 2, \mathrm{OH}^{*}\right.$ and $\left.\mathrm{LPO}\right)$ with concomitant alterations in the renal and liver tissues. However, enzymic and non-enzymic antioxidant levels were decreased. Nevertheless, an oral effective dose of E. officinalis and Z. officinalae $(120+120 \mathrm{mg} / \mathrm{kg}$ body weight/day increased the antioxidant enzymes and retrieved the altered levels of ROS and LPO that were induced by arsenic and lead. Thus, we show that E. officinalis and Z. officinalae leaf extract exhibits nephroprotective and hepatoprotective role through the restoration of reactive oxygen species and antioxidant enzymes in the kidney and liver tissue of Arsenic and Lead-induced nephrotoxicity and hepatotoxicity in rats. Hence, E. officinalis and Z. officinalae leaf extract are potential therapeutic options for the treatment of metal toxicity-induced kidney and liver diseases.

Keywords: Antioxidant enzymes, nephrotoxicity, hepatotoxicity, oxidative stress

\section{Background:}

Metals are found naturally in the environment and their compositions vary among different localities, resulting in spatial variations of surrounding concentrations. Distribution of these heavy metals in the atmosphere is affected by various environmental factors [1]. Heavy metals are usually referred to as those metals, which possess a specific density of more than $5 \mathrm{~g} / \mathrm{cm} 3$ and adversely affect the habitat and living organisms [2]. Arsenic and lead enter the surroundings by natural means and through human activities. Various routes of arsenic and lead exposure include soil erosion, natural weathering of the earth's crust, mining, industrial effluents, urban runoff, sewage discharge, insect or disease control agents applied to crops, and many others [3]. Earlier study states that oxidative deterioration of biological macromolecules is primarily due to binding of heavy metals to the DNA and nuclear proteins [4]. Indian gooseberry (Phyllanthus emblica officinalis) extracts, has been used in traditional medicine to treat symptoms ranging from constipation to cancer treatment for centuries in the Indian system of medicine [5]. E. officinalis has been shown to be a potent free radical scavenging agent, thereby preventing carcinogenesis and mutagenesis. A dose of $100 \mathrm{mg} / \mathrm{Kg}$ body weight has shown to reduce the incidence of tumour by approximately 60\% [6,7]. Ginger (Zingiber officinale Roscoe) is also another natural dietary component generally used in complementary and alternative medicine (CAM). Various ginger and ginger leaf extracts have been reported positive response in controlling cancer proliferation [8]. However, therapeutic effects of E.officinalis and Z. officinalae on metal-toxicity on multiple organ damage have not been report. Therefore, it is of interest to document the effect of E. officinalis and Z. officinalae in arsenite and lead-induced toxicity in male albino rats.

\section{Materials and methods:}

All chemicals and reagents used in the present study were molecular and analytical grade; and they were purchased from Sigma Chemical Company, St. Louis, MO, USA; Amersham Biosciences, Little Chalfont, Buckinghamshire, United Kingdom; and Sisco Research Laboratories, Mumbai, India; Arsenic and Lead was purchased from Sigma Chemicals Company, USA. Biochemical assay kits used in the present study were purchased from Spinreact, Spain.

\section{Animals:}

Animals were maintained as per the guidelines and protocols approved by the Institutional Animal's Ethics Committee and by the regulatory body of the government (IAEC No: BRULAC/SDCH/SIMATS/IAEC/09-2018/009). Healthy male albino rats of Wistar strain (Rattus norvegicus) weighing 180-210 g (150-180 days old) were used in this study. Animals were obtained and maintained in clean polypropylene cages under specific humidity $(65 \pm 5 \%)$ and temperature $\left(27 \pm 2{ }^{\circ} \mathrm{C}\right)$ with constant $12 \mathrm{~h}$ light and $12 \mathrm{~h}$ dark schedule at Biomedical Research Unit and Lab Animal Center (BRULAC), Saveetha Dental College \& Hospitals, Saveetha Institute of Medical \& Technical Sciences, Chennai - 600 077. They were fed with standard rat pelleted diet (Lipton India, Mumbai, India), and clean drinking water was made available ad libitum.

\section{Experimental design:}

We used 8 groups of adult male Wistar rats with 1 control group for this study. The animals were divided into Group I: Control and Group II: Lead and sodium arsenite-induced rats (animals were induced for metal toxicity by the combined administration of 

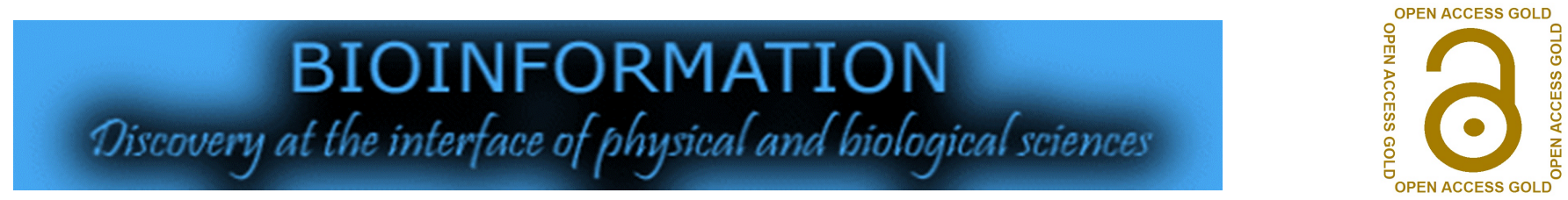

arsenic (13.8 $\mathrm{mg} / \mathrm{kg}$ body weight) and lead $(116.4 \mathrm{mg} / \mathrm{kg}$ body weight). These doses were administered by gastric intubation during 14 consecutive days using known standard procedures. Arsenic and lead induced rats treated with ethanolic extract of Emblica officinalis ( $60 \mathrm{mg} / \mathrm{kg}$ body weight/day, orally for 45 days) are group III rats. Group IV animals are arsenic and lead induced rats treated orally with ethanolic extracts of E. officinalis (120 $\mathrm{mg} / \mathrm{kg}$ body weight/day for 45 days). Group V animals are arsenic and lead induced rats treated orally with ethanolic extracts of $Z$. officinalae (60 mg/ $\mathrm{kg}$ body weight/day for 45 days). Group VI animals are arsenic and lead induced rats orally treated withethanolic extracts of Zingiber officinalis $(120 \mathrm{mg} / \mathrm{kg}$ body weight/day for 45 days). Group VII animals are arsenic and lead inducedrats treated orally with ethanolic extracts of E.officinalis and Z. officinalae $(60+60 \mathrm{mg} / \mathrm{kg}$ body weight/day for 45 days). Group VIII animals are arsenic and lead induced rats treated orally with ethanolic extracts of E. officinalis and Z. officinalae $(120+120$ $\mathrm{mg} / \mathrm{kg}$ body weight/day, orally for 45 days). Normal Control animals were treated orally with ethanolic extracts of E. officinalis $(120 \mathrm{mg} / \mathrm{kg}$ body weight) + Z.officinalae $(120 \mathrm{mg} / \mathrm{kg}$ body weight) for 45 days.

\section{Biochemical Estimation:}

\section{Assessment of liver function markers}

Liver function markers such as alanine aminotransferase (ALT), aspartate aminotransferase (AST), alkaline phosphatase (ALP) and bilirubin were measured by kit method as per the manufacturer instructions and results were expressed as $\mathrm{IU} / \mathrm{ml}$.

\section{Assessment of kidney function markers:}

Kidney function markers (urea and creatinine) were measured using biochemical-assay kits procured from Spinreact, Spain using Semi-Automated Biochemistry Analyser System (Coralab 3000) and results for thesame were expressed as $\mathrm{mg} / \mathrm{dl}$.

\section{Assessment of serum lipid markers}

Serum cholesterol (CHO), triglyceride (TG), low-density lipoproteins (LDL), high-density lipoproteins (HDL) were assessed using assay kits purchased from spin react Spain. Results were expressed as $\mathrm{mg} / \mathrm{dl}$.

\section{Measurement of oxidative stress markers:}

Lipid peroxidation (LPO) was measured by a previously published method of Devasagayam and Tarachand [9]. Hydrogen peroxide generation $\left(\mathrm{H}_{2} \mathrm{O}_{2}\right)$ was assessed by the spectrophotometric method of Pick and Keisari [10]. Hydroxyl radical $\left(\mathrm{OH}^{*}\right)$ production was quantified by the method of Puntarulo and Cederbaum [11]

\section{Antioxidant Enzymes:}

Superoxide dismutase (SOD) activity was assessed by the method of Marklund and Marklund [12]. Catalase activity (CAT) was assessed as per the method of Sinha [13]. Glutathione (GSH) peroxidase (GPx) levels were assessed by the method of Rotruck et al. [14] GSH -S-transferase (GST) activity was assessed by the method of Habig et al. [15] GSH reductase (GR) was assessed as per the method of Staal et al. [16] and reduced GSH levels were measured by the method of Moron et al. [17]

\section{Statistical Analysis:}

The data were subjected to statistical analysis using one-way analysis of variance and Duncan's multiple range test to assess the significance of individual variations between the control and treatment groups using a computer-based software (GraphPad Prism version 5). In Duncan's test, the significance was considered at the level of $p<0.05$.

\section{Results:}

Arsenic and Lead-administered rat showed elevated levels of Urea and Creatinine when compared with control. However, the body weight of the animals was significantly reduced due to Arsenic and Lead induction (Figure 1a-b). Treatment with extract of Emblica offcinalis and Zingiber officinalis at the doses of $60 \mathrm{mg} / \mathrm{kg}$ body weight did not show any effective reduction on the elevated levels of kidney markers and could not increase the body weight of the animal to that of control groups whereas Combined treatment with extract of Emblica offcinalis and Zingiber officinalis $120 \mathrm{mg} / \mathrm{kg}$ body weight dose significantly normalized the kidney function markers and improved the body weight which altered by Arsenic and Lead induction. Control rats treated with Emblica officinalis and Zingiber officinalis extract did not showed any significant change showing the effective dose of leaf extract does not have any toxicity.

Liver function markers (ALT, AST, and ALP) were significantly elevated in Arsenic and Lead-induced Toxicity in rats when compared to control. Treatment with extract of Emblica offcinalis and Zingiber officinalis at the doses of $60 \mathrm{mg} / \mathrm{kg}$ body weight could not reduce the enzyme levels to that of the control [Figure 2a-c]. However, Combined treatment with extract of Emblica offcinalis and Zingiber officinalis $120 \mathrm{mg} / \mathrm{kg}$ body weight dose significantly restored the liver function markers to control level. Control rats treated with Emblica officinalis and Zingiber officinalis extract did not showed any significant change showing the effective dose of leaf extract does not have any toxicity. 


\section{BIOINFORMATION \\ Discovery at the interface of physical and biological sciences}

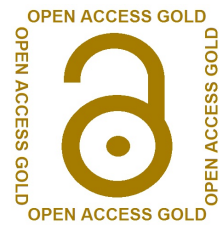

\section{Urea}

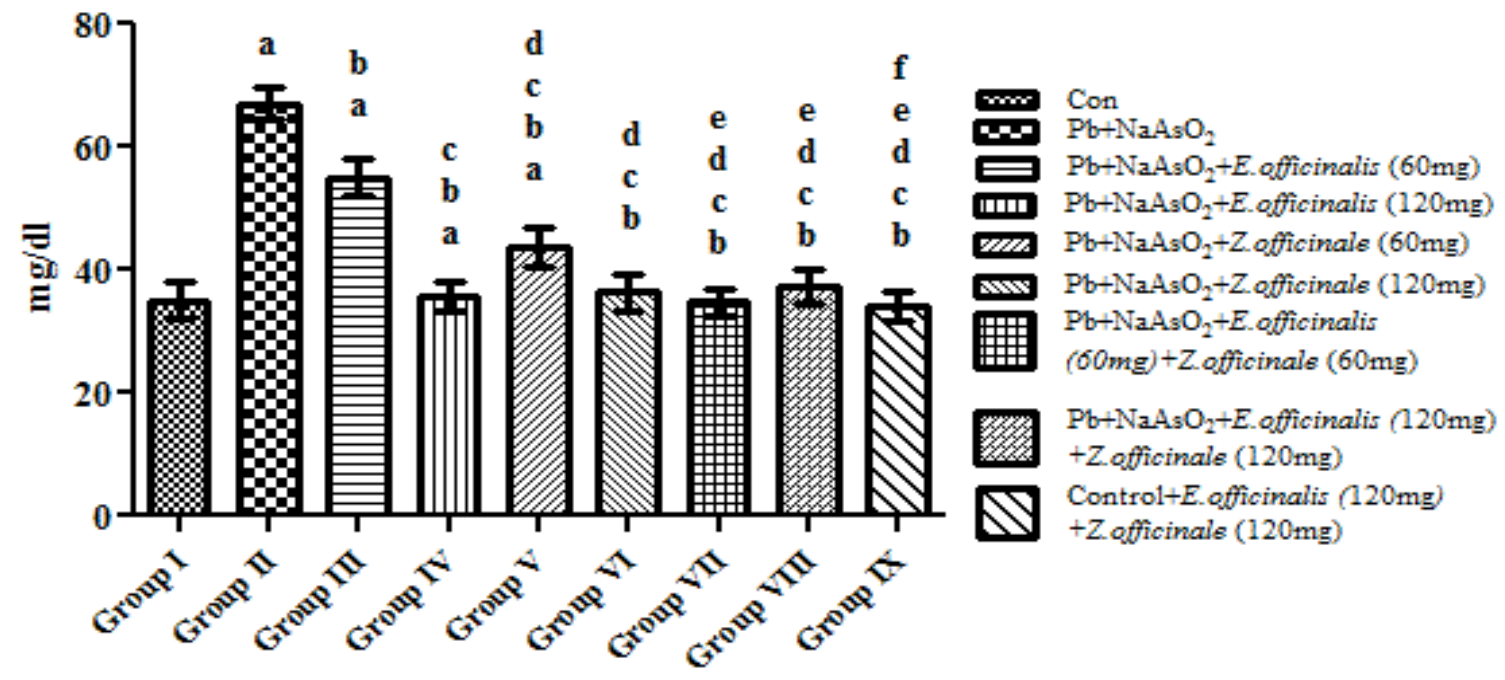

Creatinine

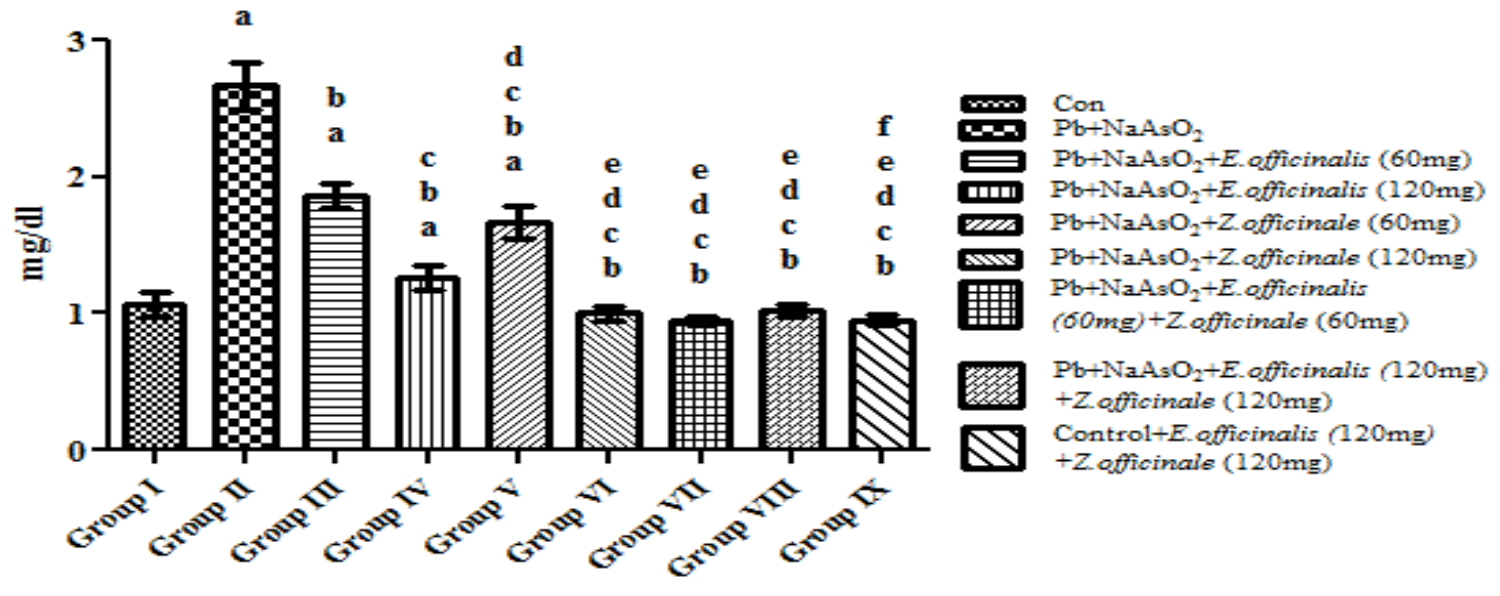

Figure 1: Effect of E. officinalis and Z. officinale on kidney function makers (Urea and Creatinine) in lead-arsenic-induced toxicity in adult male rat. Each bar represents mean \pm SEM of 6animals. Significance at $p<0.05$, a-compared with control, b-compared with Lead-Arsenic toxicity, c-compared with Lead-Arsenic toxicity rats treated with $60 \mathrm{mg}$ E.officinalis; d-compared with Lead-Arsenic toxicity rats treated with 120mg E. officinalis; e- compared with Lead-Arsenic toxicity rats treated with 60mg Z.officinale; f-compared with Lead-Arsenic toxicity rats treated with 60 E.officinalis $+60 \mathrm{mg}$ Z. officinale. 


\section{BIOINFORMATION \\ Discovery at the interface of physical and biological sciences}

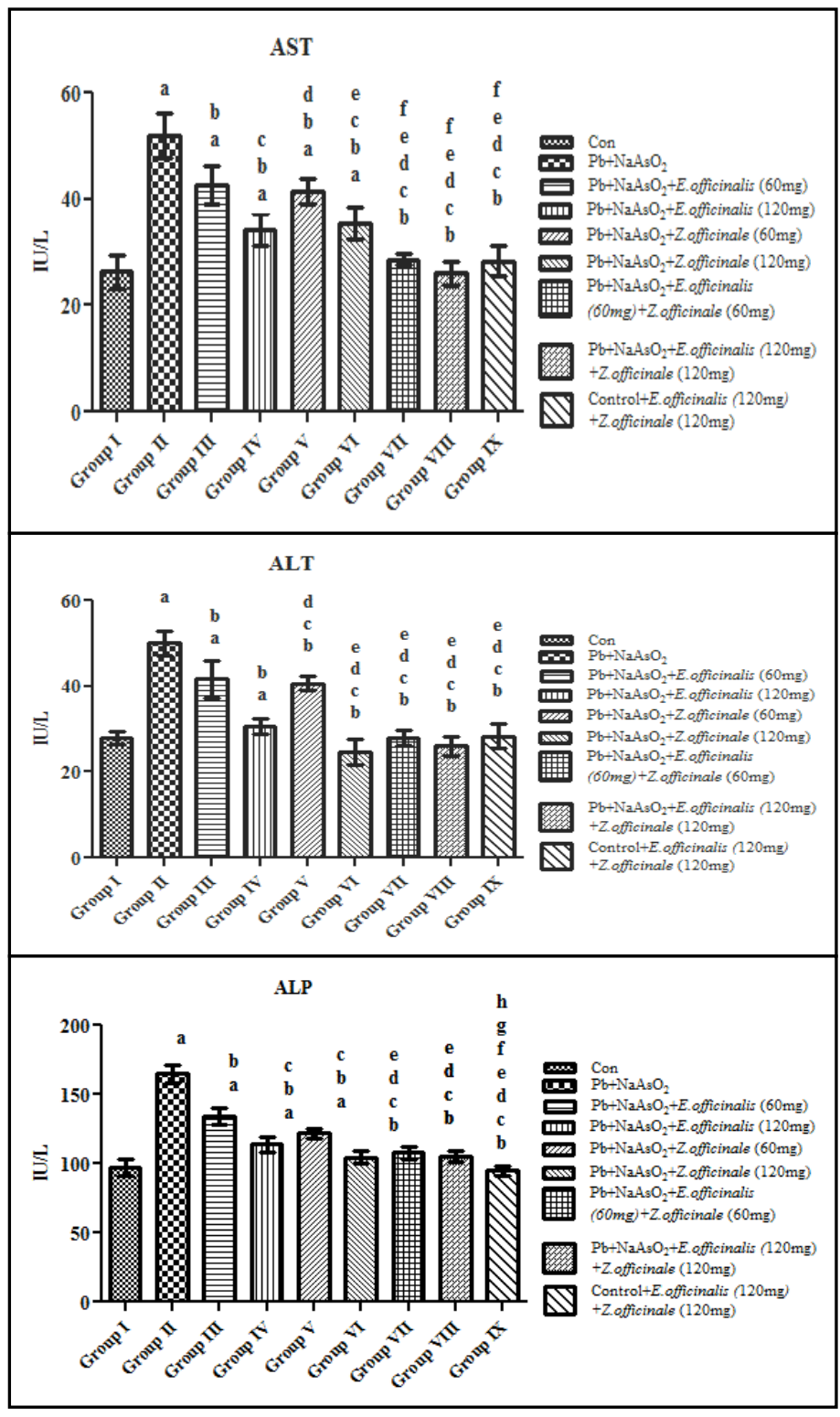

ISSN 0973-2063 (online) 0973-8894 (print)
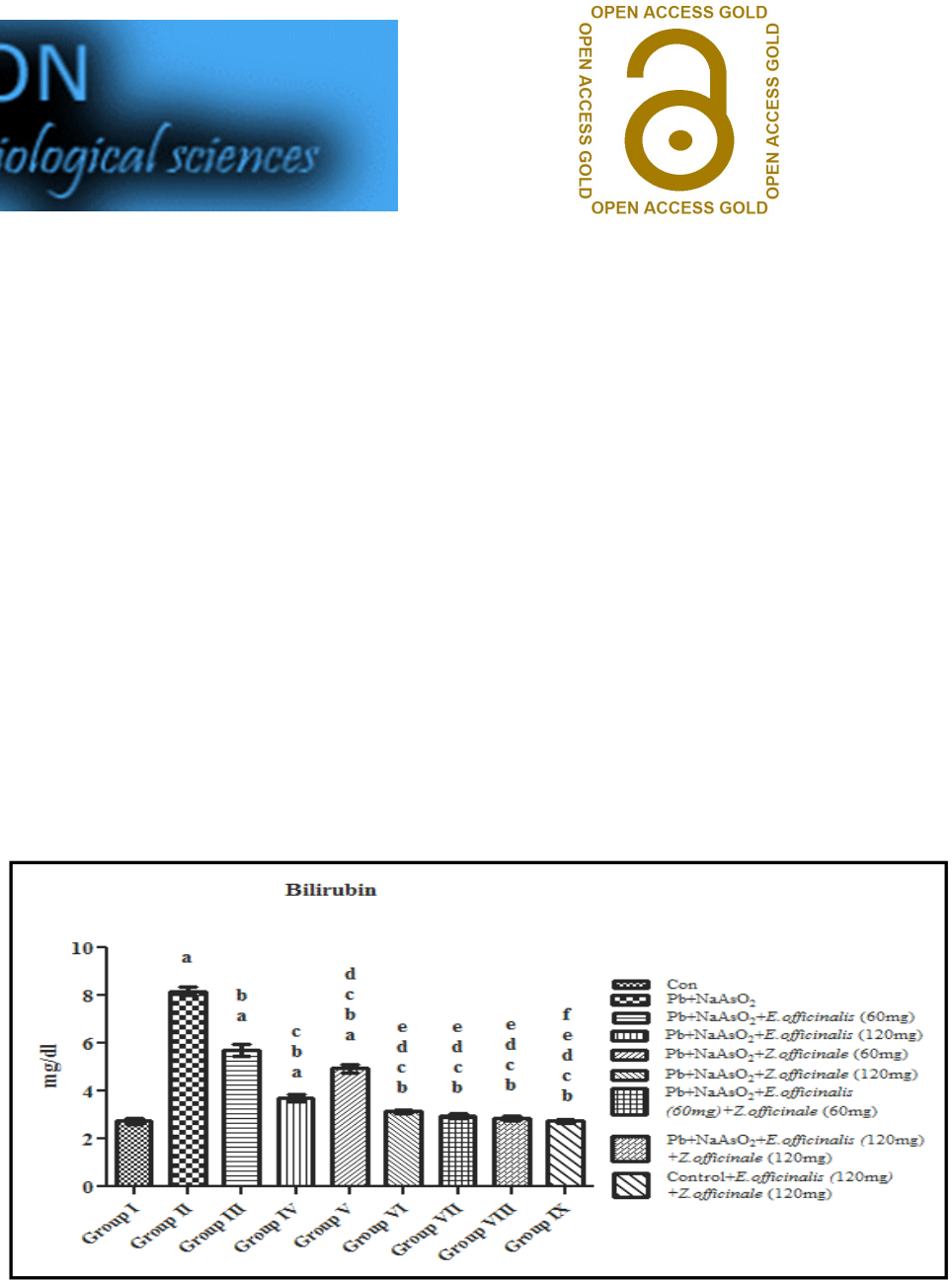

Figure 2: Effect of E.officinalis and Z.officinale on liver function markers (AST, ALT, ALP and Total Bilirubin) in lead-arsenicinduced toxicity in adult male rat. Each bar represents mean \pm SEM of 6 animals. Significance at $p<0.05$, a-compared with control, bcompared with Lead-Arsenic toxicity, c-compared with LeadArsenic toxicity rats treated with $60 \mathrm{mg}$ E.officinalis; d- compared with Lead-Arsenic toxicity rats treated with 120mg E.officinalis; ecompared with Lead-Arsenic toxicity rats treated with $60 \mathrm{mg}$ Z.officinale; f-compared with Lead-Arsenic toxicity rats treated with 60 E. officinalis $+60 \mathrm{mg}$ Z.officinale. Total and direct bilirubin levels were significantly increased in Arsenic and Lead-induced rats whereas administration of Emblica officinalis and Zingiber officinalis extract normalized the bilirubin levels to that of the control. Control rats treated with Emblica officinalis and Zingiber officinalis extract did not showed any significant change in the bilirubin levels (Figure 2d). Increased levels of Total cholesterol, TG, and LDL cholesterol (LDLC) but low HDL cholesterol (HDLC) were observed in the Arsenic-Lead induced animals. Emblica officinalis and Zingiber officinalis leaf extract treated experimental rats significantly alleviated dyslipidaemia to that control (Figure ac). 


\section{BIOINFORMATION \\ Discovery at the interface of physical and biological sciences}

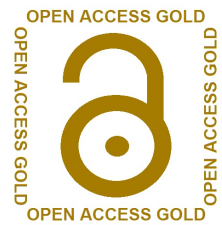

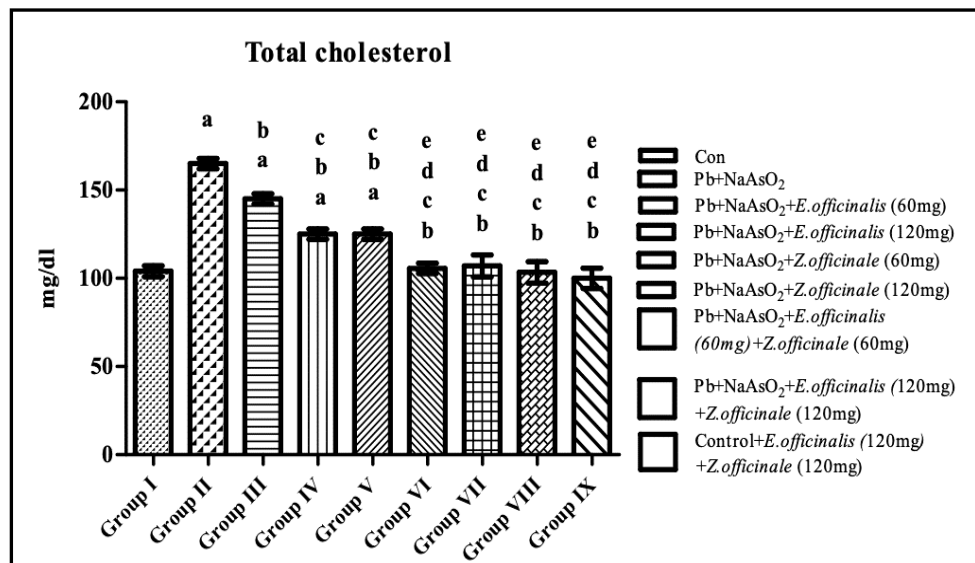

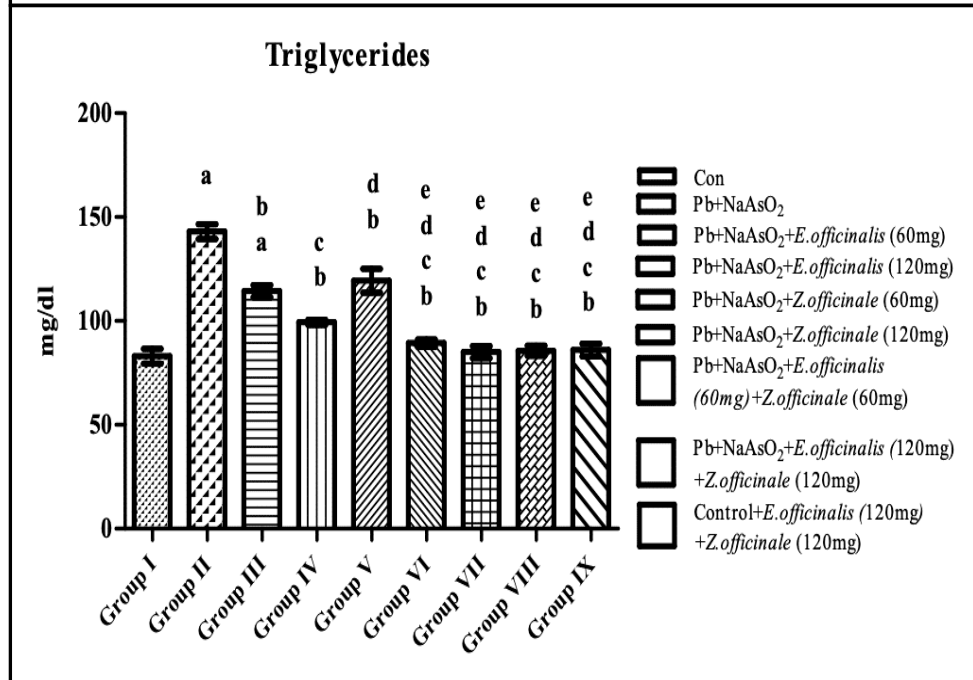

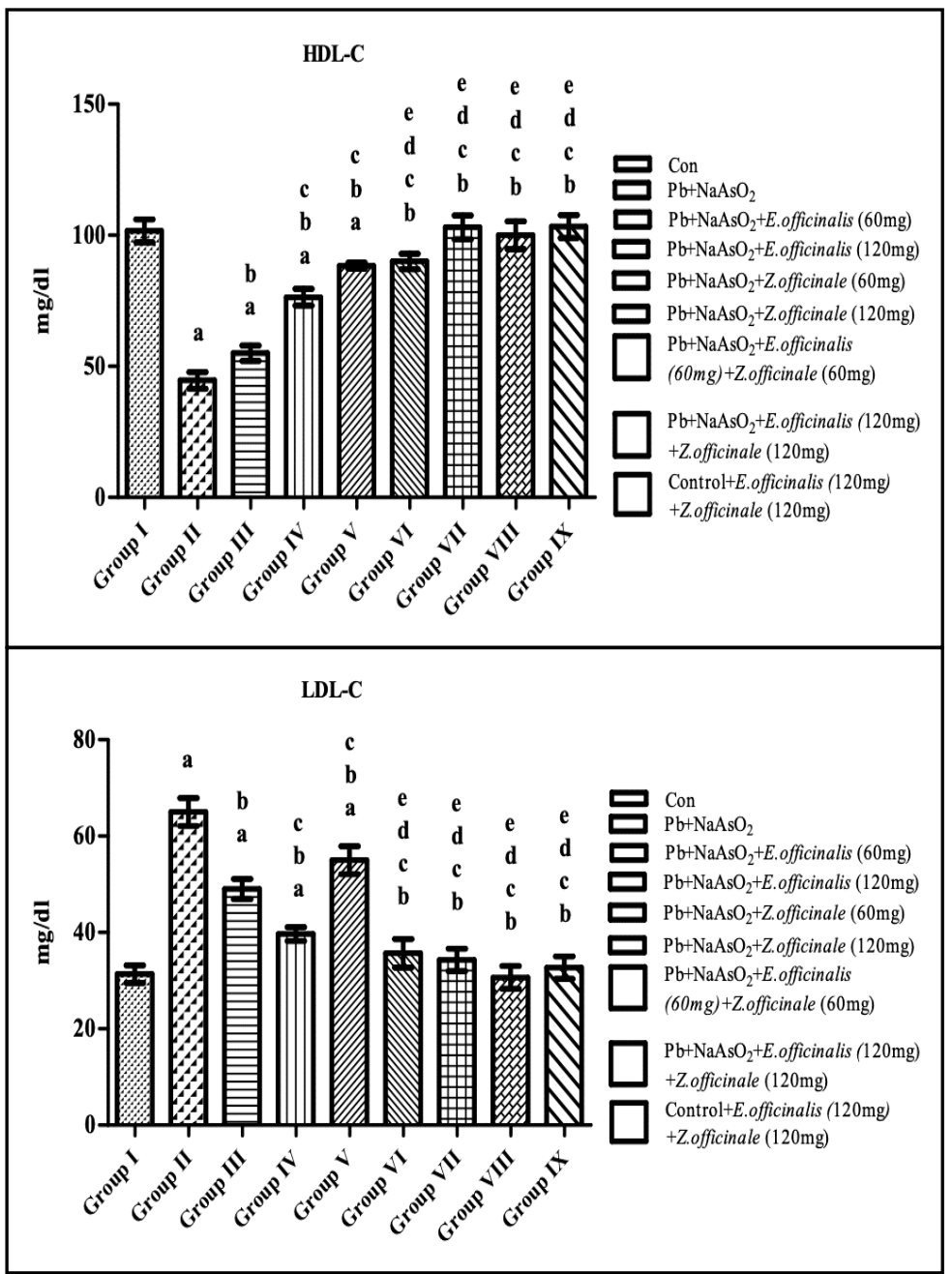

Figure 3: Effect of E.officinalis and Z.officinale on lipid biomarkers (TC, TG, HDL-c and LDL-c) in lead-arsenic-induced toxicity in adult male rat. Each bar represents mean \pm SEM of 06 animals. Significance at $\mathrm{p}<0.05$, a-compared with control, b-compared with Lead-Arsenic toxicity, c-compared with Lead-Arsenic toxicity rats treated with $60 \mathrm{mg}$ E.officinalis; d- compared with Lead-Arsenic toxicity rats treated with $120 \mathrm{mg}$ E.officinalis; e-compared with LeadArsenic toxicity rats treated with $60 \mathrm{mg}$ Z.officinale; f-compared with Lead-Arsenic toxicity rats treated with 60 E.officinalis $+60 \mathrm{mg}$ Z.officinale. 


\section{BIOINFORMATION \\ Discovery at the interface of physical and biological sciences}

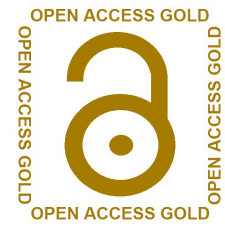

Compared to control, the $\mathrm{H} 2 \mathrm{O} 2, \mathrm{OH}^{*}$, and $\mathrm{LPO}$ in kidney were significantly raised in Arsenic-Lead induced rats. Treatment with Emblica officinalis and Zingiber officinalis leaf extract notably brought down the rise in hydrogen peroxide, $\mathrm{OH}^{*}$, and LPO (Table 1). Compared to control, the $\mathrm{H} 2 \mathrm{O} 2, \mathrm{OH}^{*}$, and $\mathrm{LPO}$ in kidney were significantly raised in Arsenic-Lead induced rats. Treatment with Emblica officinalis and Zingiber officinalis leaf extract notably brought down the rise in hydrogen peroxide, $\mathrm{OH}^{*}$, and LPO (Table 2). There was a marked decrease observed in antioxidants enzymes (SOD, CAT, GPx, GST, GR, GSH) in the kidney of Arsenic-Lead induced Toxicity group compared to control. Emblica officinalis and Zingiber officinalis efficiently increased the level of antioxidant enzymes compared to the induced group due to the presence of antioxidants in the extract (Table 3). There was a marked decrease observed in antioxidants enzymes (SOD, CAT, GPx, GST,) in the kidney of Arsenic-Lead induced Toxicity group compared to control. Emblica officinalis and Zingiber officinalis efficiently increased the level of antioxidant enzymes compared to the induced group due to the presence of antioxidants in the extract (Table 4).

Table 1: Effect of E.officinalis and Z. officinale on oxidative stress $\left(\mathrm{H}_{2} \mathrm{O}_{2 \&} \mathrm{OH}^{*}\right)$ and lipid peroxidation (LPO) in the kidney tissue of leadarsenic-induced toxicity in adult male rat. Each bar represents mean \pm SEM of 6 animals. Significance at $\mathrm{p}<0.05$, a-compared with control, b-compared with Lead-Arsenic toxicity, c-compared with Lead-Arsenic toxicity rats treated with 60mg E.officinalis; d- compared with LeadArsenic toxicity rats treated with $120 \mathrm{mg}$ E.officinalis; e-compared with Lead-Arsenic toxicity rats treated with $60 \mathrm{mg}$ Z.officinale; f-compared with Lead-Arsenic toxicity rats treated with 60 E.officinalis $+60 \mathrm{mg}$ Z.officinale.

\begin{tabular}{|c|c|c|c|c|c|c|c|c|c|}
\hline Parameters & $\begin{array}{l}\text { Group } \\
\text { I }\end{array}$ & Group II & Group III & Group IV & Group V & Group VI & Group VII & Group VIII & Group IX \\
\hline $\mathrm{H}_{2} \mathrm{O}_{2}$ & $1 \pm 0.111$ & $2.9 \pm 0.27^{a}$ & $2.0 \pm 0.10^{\mathrm{ab}}$ & $1.8 \pm 0.17 \mathrm{abc}$ & $1.2 \pm 0.57 \mathrm{bcd}$ & $1 \pm 0.05^{\mathrm{bcd}}$ & $1.2 \pm 0.05^{\mathrm{bcd}}$ & $1.13 \pm 0.08^{\mathrm{bcd}}$ & $1.15 \pm 0.02^{\mathrm{bcd}}$ \\
\hline LPO & $10 \pm 0.98$ & $21 \pm 0.88^{a}$ & $18 \pm 0.57 \mathrm{ab}$ & $13 \pm 0.57 \mathrm{bcd}$ & $11 \pm 0.5^{\mathrm{bcd}}$ & $11.67 \pm 0.8^{\mathrm{bcd}}$ & $11.3 \pm 0.87 \mathrm{bcd}$ & $8.3 \pm 0.3$ bcdefg & $8.6 \pm 0.8^{\text {bcdefg }}$ \\
\hline
\end{tabular}

Units: 1. $\mathrm{H}_{2} \mathrm{O}_{2}-\mu \mathrm{mol} / \mathrm{ming} / \mathrm{mg}$ protein,

2. $\mathrm{OH}^{*}-\mu \mathrm{mol} / \mathrm{ming} / \mathrm{mg}$ protein

3. LPO-nmoles MDA formed/min/mg protein

Table 2: Effect of E.officinalis and Z.officinale on oxidative stress $\left(\mathrm{H}_{2} \mathrm{O}_{2}\right)$ and lipid peroxidation (LPO) in the liver of lead-arsenic-induced toxicity in adult male rat. Each bar represents mean \pm SEM of 6 animals. Significance at $p<0.05$, a-compared with control, b-compared with Lead-Arsenic toxicity, c-compared with Lead-Arsenic toxicity rats treated with $60 \mathrm{mg}$ E.officinalis; d-compared with Lead-Arsenic toxicity rats treated with $120 \mathrm{mg}$ E.officinalis; e-compared with Lead-Arsenic toxicity rats treated with 60mg Z.officinale; f-compared withLeadArsenic toxicity rats treated with 60 E.officinalis+60mg G. officinale.

\begin{tabular}{llllllllll}
\hline Parameters & Group I & Group II & Group III & Group IV & Group V & Group VI & Group VII & Group VIII & Group IX \\
\hline $\mathrm{H}_{2} \mathrm{O}_{2}$ & $2.03 \pm 0.21$ & $4.7 \pm 0.07 \mathrm{a}$ & $3.3 \pm 0.12^{\mathrm{ab}}$ & $2.43 \pm 0.17 \mathrm{abc}$ & $3 \pm 0.08^{\mathrm{abd}}$ & $1.6 \pm 0.08^{\mathrm{abcd}}$ & $1.4 \pm 0.08^{\mathrm{abcd}}$ & $1.34 \pm 0.03^{\mathrm{abcd}}$ & $1.36 \pm 0.05^{\mathrm{abcd}}$ \\
$\mathrm{LPO}$ & $12 \pm 1.15$ & $31 \pm 2.02^{\mathrm{a}}$ & $24 \pm 2.0^{\mathrm{ab}}$ & $19 \pm 0.57^{\mathrm{abc}}$ & $17 \pm 1.15^{\mathrm{abc}}$ & $13 \pm 0.57^{\mathrm{abcd}}$ & $12 \pm 0.57^{\mathrm{bcd}}$ & $11 \pm 0.8^{\mathrm{bcd}}$ & $13 \pm 0.52^{\mathrm{bcde}}$ \\
$\mathrm{OH}^{*}$ & $8 \pm 0.5$ & $20 \pm 0.5^{\mathrm{a}}$ & $15 \pm 0.5^{\mathrm{ab}}$ & $11 \pm 0.57 \mathrm{abc}$ & $12 \pm 0.50^{\mathrm{abc}}$ & $9.5 \pm 0.28^{\mathrm{abcde}}$ & $9 \pm 0.5^{\mathrm{bcde}}$ & $8 \pm 0.57 \mathrm{bcde}$ & $8.3 \pm 0.8^{\mathrm{bcde}}$ \\
\hline
\end{tabular}

Units: 1. $\mathrm{H}_{2} \mathrm{O}_{2}-\mu \mathrm{mol} / \mathrm{ming} / \mathrm{mg}$ protein

2. $\mathrm{OH}^{*}-\mu \mathrm{mol} / \mathrm{ming} / \mathrm{mg}$ protein

3. LPO-nmoles MDA formed/min/mg protein

Table 3: Effect of E.officinalis and Z.officinale on antioxidant enzymes in the kidney of lead-arsenic-induced toxicity in adult male rat. Each bar represents mean \pm SEM of 6 animals. Significance at $\mathrm{p}<0.05$, a-compared with control, b-compared with Lead-Arsenic toxicity, ccompared with Lead-Arsenic toxicity rats treated with $60 \mathrm{mg}$ E.officinalis; d- compared with Lead-Arsenic toxicity rats treated with $120 \mathrm{mg}$ E.officinalis; e-compared with Lead-Arsenic toxicity rats treated with 60mg Z.officinale.

\begin{tabular}{llllllllll}
\hline Parameters & Group & Group & Group & Group & Group & Group & Group & Group & Group IX \\
& I & II & III & IV & V & VI & VII & VIII & \\
\hline CAT & $40 \pm 1.7$ & $20 \pm 0.8^{\mathrm{a}}$ & $26 \pm 2.3^{\mathrm{ab}}$ & $32 \pm 1.4^{\mathrm{abc}}$ & $33 \pm 1.7$ abc & $41 \pm 0.8^{\text {bcde }}$ & $39 \pm 0.3^{\mathrm{bcf}}$ & $40 \pm 1.15^{\mathrm{bcde}}$ & $42 \pm 1.4^{\text {bcde }}$ \\
GPx & $32 \pm 1.4$ & $16 \pm 1.15^{\mathrm{a}}$ & $21 \pm 0.6^{\mathrm{ab}}$ & $27 \pm 1.4^{\text {bc }}$ & $32 \pm 1.15$ bcd & $34 \pm 2.6^{\text {bcd }}$ & $36 \pm 2.6^{\text {bcd }}$ & $38 \pm 3.05^{\mathrm{bcd}}$ & $34 \pm 2.088^{\mathrm{bcd}}$ \\
GST & $25 \pm 2.3$ & $14 \pm 1.15$ & $17 \pm 1.4$ & $24 \pm 1.15$ & $22 \pm 1.15$ & $22 \pm 0.5$ & $24 \pm 1.4$ & $26 \pm 1.7$ & $28 \pm 1.52$ \\
SOD & $35 \pm 2.3$ & $16 \pm 1.15$ & $22 \pm 1.5$ & $31 \pm 1.3$ & $28 \pm 2.02$ & $32 \pm 1.15$ & $33 \pm 1.5$ & $36 \pm 1.8$ & $36 \pm 3.05$ \\
\hline
\end{tabular}



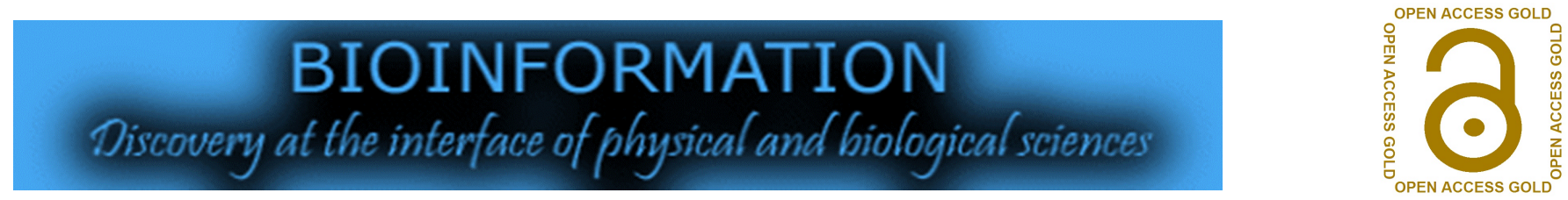

Table 4: Effect of E.officinalis and Z. officinale on antioxidant enzymes in liver of lead-arsenic-induced toxicity in adult male rat. Each bar represents mean \pm SEM of 6 animals. Significance at $p<0.05$, a-compared with control, b-compared with Lead-Arsenic toxicity, c-compared with Lead-Arsenic toxicity rats treated with $60 \mathrm{mg}$ E. officinalis; d-compared with Lead-Arsenic toxicity rats treated with $120 \mathrm{mg}$ E.officinalis; e-compared with Lead-Arsenic toxicity rats treated with $60 \mathrm{mg}$ Z. officinale

\begin{tabular}{|c|c|c|c|c|c|c|c|c|c|}
\hline Parameters & $\begin{array}{l}\text { Group } \\
\text { I }\end{array}$ & $\begin{array}{l}\text { Group } \\
\text { II }\end{array}$ & $\begin{array}{l}\text { Group } \\
\text { III }\end{array}$ & $\begin{array}{l}\text { Group } \\
\text { IV }\end{array}$ & $\begin{array}{l}\text { Group } \\
\text { V }\end{array}$ & $\begin{array}{l}\text { Group } \\
\text { VI }\end{array}$ & $\begin{array}{l}\text { Group } \\
\text { VII }\end{array}$ & $\begin{array}{l}\text { Group } \\
\text { VIII }\end{array}$ & $\begin{array}{l}\text { Group } \\
\text { IX }\end{array}$ \\
\hline CAT & $65 \pm 2.8$ & $35 \pm 2.8^{\mathrm{a}}$ & $44 \pm 3.0^{\mathrm{b}}$ & $55 \pm 2.8^{\mathrm{abc}}$ & $53 \pm 3.5^{\mathrm{abc}}$ & $61 \pm 5.7 \mathrm{bc}$ & $61 \pm 5.7 \mathrm{bc}$ & $64 \pm 2.9 \mathrm{bc}$ & $61 \pm 4.4^{\mathrm{bc}}$ \\
\hline GPx & $54 \pm 4.2$ & $21 \pm 1.8^{a}$ & $33 \pm 1.6^{\mathrm{ab}}$ & $38 \pm 1.5^{\mathrm{ab}}$ & $46 \pm 3.3 \mathrm{abcd}$ & $50 \pm 2.8 \mathrm{bcd}$ & $50 \pm 5.78^{\mathrm{bcd}}$ & $48 \pm 4.48^{\mathrm{bcd}}$ & $51 \pm 1.88^{\mathrm{bcd}}$ \\
\hline GST & $35 \pm 2.8$ & $17 \pm 1.3 \mathrm{a}$ & $23 \pm 2.0 \mathrm{ab}$ & $30 \pm 0.8 \mathrm{abc}$ & $29 \pm 2.0 \mathrm{ab}$ & $35 \pm 2.8^{\mathrm{bc}}$ & $34 \pm 2.3 \mathrm{bc}$ & $37 \pm 1.5^{\mathrm{bc}}$ & $36 \pm 2.3 b c$ \\
\hline SOD & $55 \pm 2.9$ & $32 \pm 1.7$ a & $42 \pm 1.5^{\mathrm{ab}}$ & $48 \pm 1.6^{\mathrm{ab}}$ & $50 \pm 2.8 \mathrm{abc}$ & $56 \pm 1.0^{\mathrm{bcd}}$ & $51 \pm 1.8^{\mathrm{bcd}}$ & $55 \pm 2.8^{\mathrm{bcd}}$ & $53 \pm 4.4 \mathrm{bcd}$ \\
\hline
\end{tabular}

\section{Discussion:}

It is of interest to determine the effects of Lead-Arsenic induced oxidative damage and role of Emblica officinalis and Zingiber officinalis in Lead-Arsenic methylation metabolism. Arsenic is one of the most important naturally occurring toxic metalloid causing concern from both ecological and individual health viewpoints [18]. Arsenic ranks twentieth among the elements in abundance in earth's crust and its inorganic forms such as arsenite and arsenate compounds are lethal to the environment and living creatures. Exposure of arsenic to humans may occur by drinking contaminated water, cigarettes, industrial source, food or from unintended sources. Among the various routes of exposure drinking water is one of the largest sources of arcenicosis. Contamination of drinking water occurs by the use of arsenical pesticides, natural mineral deposits or inappropriate disposal of arsenical chemicals. Intentional consumption of arsenic in case of suicidal attempts or accidental consumption by children may also result in cases of acute poisoning $[\mathbf{1 8 , 1 9 ]}$. Arsenic primarily affects the sulfhydryl group of cells causing malfunctioning of cell respiration, cell enzymes and mitosis [20]. Arsenic (usually as arsenic trioxide, As2O3) is well known as a poison and has been discovered to be a carcinogen in humans. Extreme levels of arsenic exposure occur mainly in localities where arsenic is found naturally i.e. soils, rocks, and water, and in workplaces, near or in risky waste sites. Chronic exposure to inorganic arsenic can lead to cancer of the skin, lungs, bladder, and liver if the exposure is through ingestion. Lung cancer can occur if exposure is by inhalation $[21,22]$. Low levels of arsenic exposure for prolonged periods of time can give rise to discoloration of the skin and the appearance of small corns or warts [23]. High levels of arsenic exposure can cause death. Lead $(\mathbf{P b})$ is ubiquitous and naturally occurring bluish grey metal found in small amount in earth crust and has been recognized as a major health hazard for living organisms on the earth. High malleability, low melting point, ductility softness and resistance to corrosion, are some of the unique properties of lead. Lead has been used in different industries like automobiles, paint, ceramics, plastics, etc. The sources of lead exposure include mainly industrial processes, food and smoking, drinking water and domestic sources. Lead remains present in the atmosphere (water, soil or industrial products) because of its persistent nature. Worldwide reports suggest that children are more susceptible to lead as gastrointestinal absorption is higher and blood lead levels lower than $10 \mu \mathrm{g} / \mathrm{dl}$ may also cause serious manifestations like slowed cognitive development and neuropsychological disorders $[\mathbf{2 4}, \mathbf{2 5}, \mathbf{2 6}]$. The liver function marker enzymes (ALT, AST, and ALP) and the bilirubin levels in serum are long-standing indicator of hepatotoxicity [27]. We observed a significant increase in the levels of ALT, AST, and ALP and total bilirubin in Arsenic-Lead administered experimental rats which suggesting their cellular leakage and loss of functional integrity of cell membrane in liver. E.officinalis and Z.officinal ethanolic leaf extract treatment significantly decreased the liver function marker enzymes and bilirubin toward the respective normal level that is an indication of stabilization of plasma membrane as well as repair of hepatic tissue damage caused by the Arsenic-Lead administration. Karadka Ramdas Thilakchand et al. [28] demonstrated that hepatoprotective actions of amla is mediated by its free radical scavenging, antioxidant, anti-inflammatory, modulation of the xenobiotic detoxification process and lipid metabolism. Urea and creatinine levels in serum are crucial biomarkers of renal function in human and animal studies [29]. Data from the present study revealed that Arsenic-Lead administration caused a significant increase in urea and creatinine and levels may be due to decreased glomerular filtration rate, which is an indication of loss of renal function. This may attribute to oxidative stress-induced cellular damage induced by Arsenic-Lead administration. Considering, treatment with E. officinalis and $Z$. officinale ethanolic leaf extract significantly restored the altered levels of urea and creatinine, which may be due to the repair of renal tissue damage mediated by the antioxidants potential of extracts. We also observed that Arsenic-Lead administration significantly increased the level of total cholesterol (TC) and that may be due to increased activity of lipogenic enzymes mediated by Arsenic-Lead [30]. An elevated levels of FFA, LDL, and VLDL also observed in Arsenic-Lead induced toxicity in rats that may be due to the stimulation of sympathetic adrenal system by Arsenic-Lead leading to increased secretion of 

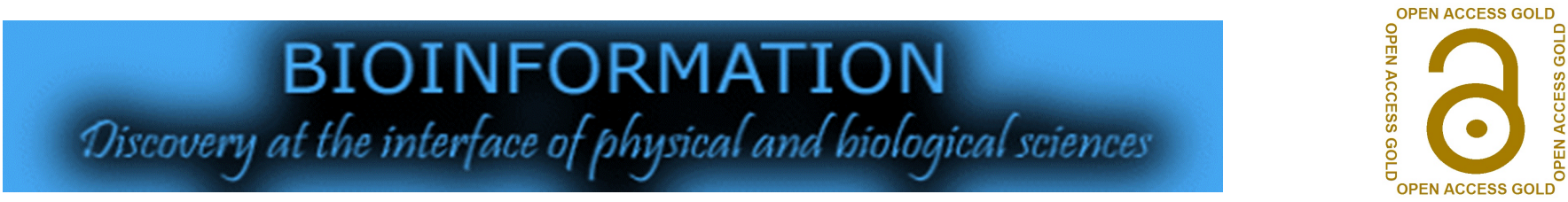

catecholamines resulting in increased lipolysis and synthesis of TGrich lipoproteins [32,33]. A concomitant decrease in the level of HDL was also observed in Arsenic-Lead administered rats as a result of decreased activity of lipoprotein lipase and $\mathrm{CHO}$ acyltransferase due to Arsenic-Lead administration. E.officinalis and Z. officinale ethanolic leaf extract treatment significantly decreased the elevated levels of TC, FFA, LDL, and VLDL and concomitantly increased the level of HDL in experimental rats which may due to the presence of a biologically active compound that modulates the lipid metabolism by decreasing the oxidative stress. Moreover, the finding of the current study indicates that the exposure of Arsenic-Lead results in elevated levels of LPO, H2O2, and ${ }^{*} \mathrm{OH}$ that may be due to enhanced activity of Either redoxactive or redox-inactive metals may cause an increase in production of reactive oxygen species (ROS) such as hydroxyl radical (HO.), superoxide radical (O2.-) or hydrogen peroxide (H2O2). Enhanced generation of ROS can overwhelm cells' intrinsic antioxidant defences, and result in a condition known as "oxidative stress". Cells under oxidative stress display various dysfunctions due to lesions caused by ROS to lipids, proteins and DNA [34]. An elevated levels of LPO is associated with a wide variety of toxic effects, including decreased membrane fluidity and function, impaired functions of the mitochondria and Golgi apparatus and inhibition of enzymes which results in tissue damage and organ dysfunction [35]. We also found a significant decline in antioxidant enzymes includes SOD, CAT, GPx, GST, GR, and GSH was also observed in Arsenic-Lead administered rats. This may be due to increased utilization of antioxidants to scavenge excess ROS induced by Arsenic-Lead. The treatment with E. officinalis and Z. officinale ethanolic leaf extract significantly decreased the level of ROS with elevating the antioxidant enzymes in Arsenic-Lead induced nephrotoxic rats that may be due to the presence of antioxidants in the extract.

\section{Conclusion:}

The kidney (urea and creatinine) and liver function markers (ALP, AST, ALT, and BR), and lipid markers (LDL, HDL, VLDL, TG, and FFA) were found to be altered in Arsenic-Lead induced rats. Antioxidants (SOD, CAT, GPx, GST, and GR,) are altered due to Arsenic-Leadinduced toxicity. Treatment with the effective dose $(120 \mathrm{mg} / \mathrm{kg}$ b.wt) of E.officinalis and Z.officinaleleaf extract significantly improved the altered levels of the biochemical profiles. Thus, E.officinalis and Z.officinale exhibit protective role through the restoration of serum biochemical profiles and antioxidant enzymes in the kidney and liver tissue of arsenic-lead induced toxicity in male rats. Further studies are needed to elucidate the exact mechanisms of protective role of E. officinalis and Z. officinale to ascertain its potential.

\section{Acknowledgements:}

The authors wish to thank the Department of Bio-chemistry, Saveetha Dental College \& Hospitals, Biomedical Research Unit and Lab Animal Center (BRULAC), Saveetha Institute of Medical \& Technical Sciences, Chennai - 600 077, India, for providing laboratory facilities.

\section{References:}

[1] Adonaylo VN and Oteiza PI Toxicology 1999 135:77. [PMID: 10463764]

[2] Bates MN et al. Am J Epidemiology 1992 135:462. [PMID: 1570813]

[3] Brochin R et al. GU J Health Sci 2008 5:1.

[4] Chen YC et al. J Cell Physiol 1998 177:324. [PMID: 9766529]

[5] Bhatt Id et al. Food Chem 2017 215:84.

[6] Wang CC et al. Integr Cancer Ther 2017 16:505.

[7] De A et al. Oncotarget 2016 7:31484.

[8] Susanti Sk et al. Int J Pharm Phytochem Res 2017 9:129.

[9] Devasagayam TP and Tarachand U BiochemBiophys Res Commun 1987 145:134. [PMID: 3593335]

[10] Pick E and Keisari Y Cell Immunol 1981 59:301. [PMID: 6269759]

[11] Puntarulo S and Cederbaum AI. ArchBiochemBiophys1988 264:482. [PMID: 2840858]

[12] Marklund S and Marklund G Eur J Biochem 1974 47:469.

[13] Sinha AK, Anal Biochem 1972 47:389.

[14] Rotruck JT et al. Science 1973 179:588.

[15] Habig WH et al. J Biol Chem 1974 249:7130. [PMID: 4436300]

[16] Staal GE et al. Biochim Biophys Acta 1969 185:39. [PMID: 5796111].

[17] Moron MS et al. BiochimBiophys Acta 1979 582:67.

[18] Chakraborti D et al. Talanta 2002 58:3. [PMID: 18968730].

[19] Flora SJ et al. Indian J Med Res 2008 128:501. [PMID: 19106443]

[20] Gordon JJ and Quastel JH Biochem J 1948 42:337. [PMID: 16748292].

[21] Regelson W et al. Cancer 1968 21:514. [PMID: 5688987]

[22] Prystowsky SD et al. Arch Dermatol 1978 114:602. [PMID: 646380]

[23] Guha Mazumder DN et al. Int J Epidemiol 1998 27:871. [PMID: 9839746]

[24] Sinicropi MS et al. Arch Toxicol. 2010 84:501. [PMID: 20386880]

[25] Pachauri V et al. Toxicol. Appl. Pharmacol. 2009 240:255.

[26] Murata K et al. J. Occup. Hlth. 2009 51:1. [PMID: 18987427]. 


\section{BIOINFORMATION \\ Diseovery at the interface of physical and biological Scciencess}

[27] Olayinka ET and Ore A Toxics 2015 3:373. [PMID: 29051470]

[28] Karadka Ramdas Thilakchand ${ }^{1}$, Rashmi Teresa Mathai, Paul Simon, Rithin T Ravi, Manjeshwar Poonam Baliga-Rao, Manjeshwar Shrinath Baliga Hepatoprotective properties of the Indian gooseberry (Emblica officinalis Gaertn): a review 2013 4:1431.

[29] Ferguson MA and Waikar SS, Clin Chem 2012 58:680. [PMID: 22311920]
[30] Martin S and Griswold W, Environ Sci Technol Briefs Citi 2009 15:1.

[31] MA Garcia-Sevillano et al. Biometals 2013 26: 651.

[32] H. Zhong et al., Gigascience 2017 6:1

[33] Y Lopez-Hernandez et al. International Journal of Molecular Sciences 2019 20:5. [PMID: 30857174]

[34] N Ercal et al. Curr Top Med Chem 2001 1:529. [PMID: 11895129]

[35] Maiti S et al. Environ. Tox. Pharmacol. 20008 227. [PMID: 10996542]

Edited by $P$ Kangueane

Citation: Fazal et al. Bioinformation 17(2): 295-305 (2021) License statement: This is an Open Access article which permits unrestricted use, distribution, and reproduction in any medium, provided the original work is properly credited. This is distributed under the terms of the Creative Commons Attribution License

\section{Articles published in BIOINFORMATION are open for relevant post publication comments and criticisms, which will be published immediately linking to the original article for FREE of cost without open access charges. Comments should be concise, coherent and critical in less than 1000 words.}




\section{BIOINFORMATION}

Discovery at the interface of physical and biological sciences
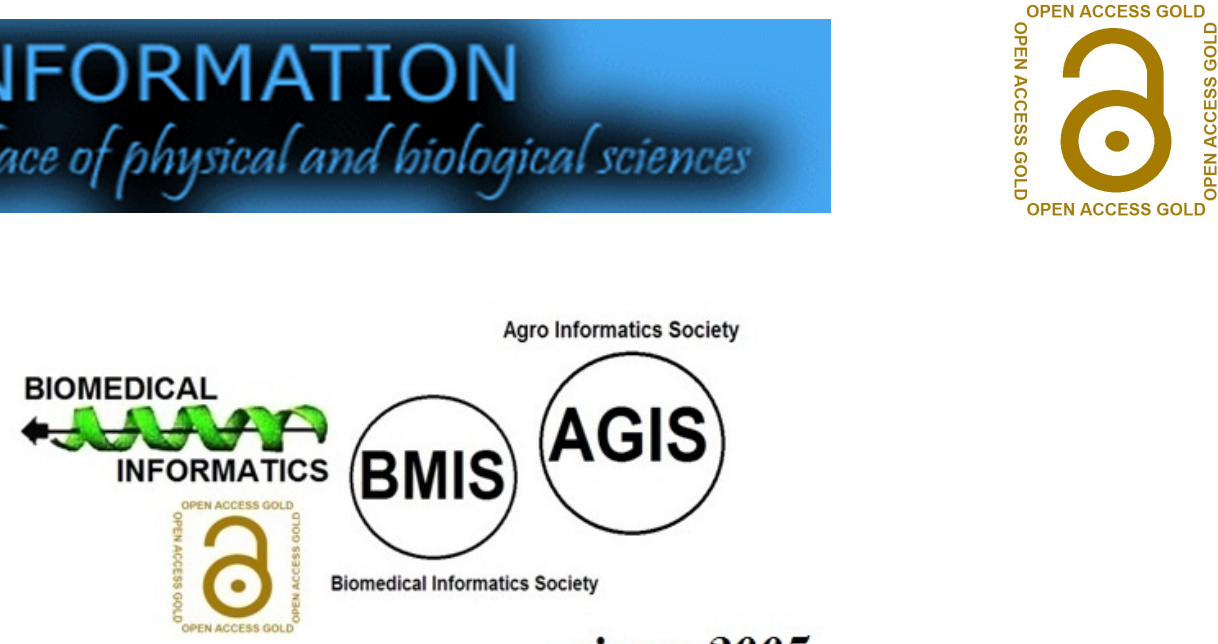

since 2005

\section{BIOINFORMATION}

Discovery at the interf ace of physical and biological sciencess

\section{indexed in}

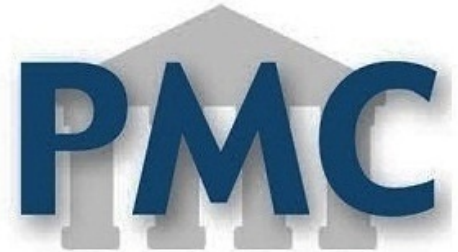

PublMed

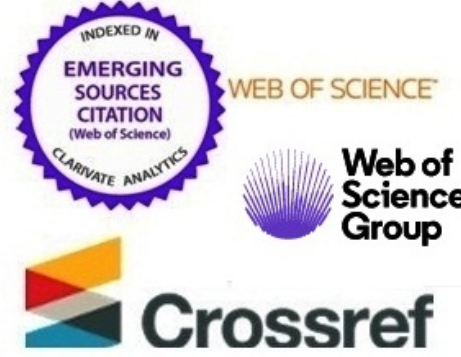

EBSCO

ResearchGate
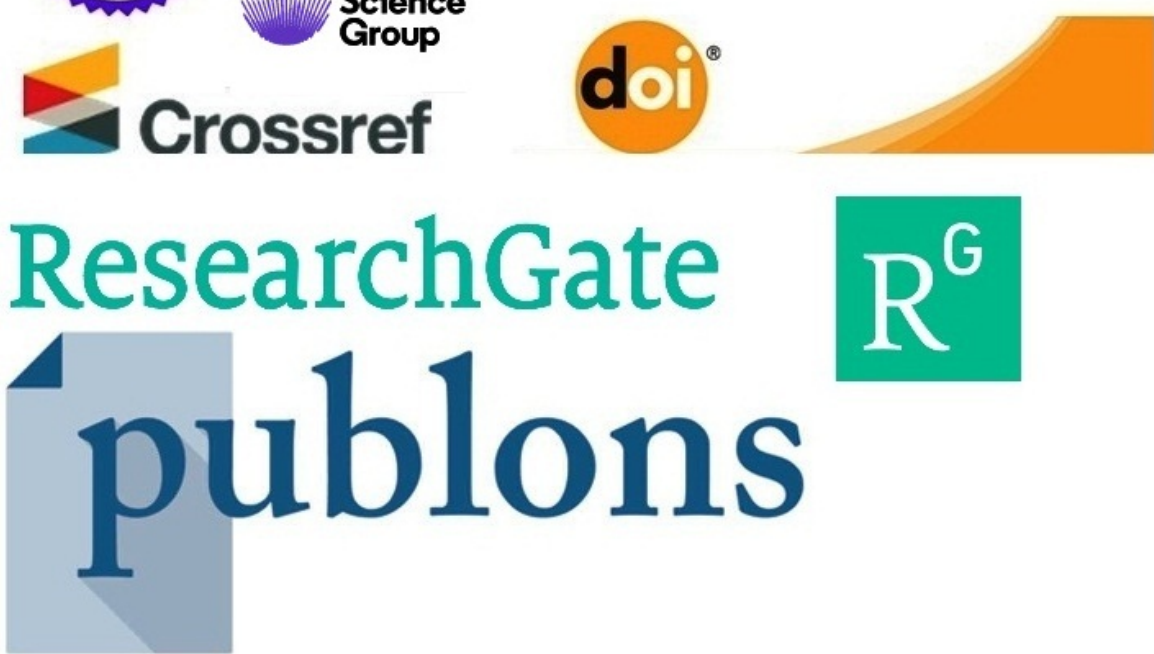